\title{
CHEMICAL COMPOSITION OF SPRING RAPESEED GROWN IN COPPER- CONTAMINATED SOIL AMENDED WITH HALLOYSITE AND ZEOLITE
}

\author{
Maja Radziemska', Zbigniew Mazur² \\ 1 Warsaw University of Life Sciences-SGGW, Faculty of Civil and Environmental Engineering, \\ Nowoursynowska 159,02-773 Warsaw, Poland, e-mail: maja_radziemska@sggw.pl \\ 2 University of Warmia and Mazury in Olsztyn, Faculty of Environmental Management and Agriculture, \\ PI. Łódzki 4, 10-727 Olsztyn, Poland, e-mail: zbigniew.mazur@uwm.edu.pl
}

Received: 2016.10.28

Accepted: 2016.12.03

Published: 2017.03.01

\begin{abstract}
The purpose of this study was to determine the effect of soil contamination with copper doses of $0,150,300$, and $450 \mathrm{mgkg}^{-1}$ of soil and the application of zeolite, raw and modified halloysite on the biomass of spring rapeseed and the content of nitrogen compounds and macronutrients in the above-ground parts of the tested plants. The content of macronutrients in plants was determined spectrophotometrically. The applied soil amendments and copper doses led to significant variations in the concentrations of the analyzed nutrients in spring rapeseed. Zeolite and halloysite were most effective in increasing the average above-ground biomass of the tested plants. Zeolite had a beneficial effect on the content of total nitrogen, ammonia nitrogen and phosphorus in the above-ground parts of spring rapeseed. Raw halloysite increased the content of sodium and calcium, whereas modified halloysite contributed to an increase in the nitrogen, potassium, sodium, calcium and magnesium content of the tested plants.
\end{abstract}

Keywords: halloysite, macronutrients, $\mathrm{Cu}$-contamination, spring rapeseed, zeolite

\section{INTRODUCTION}

Expansive human activities lead to environmental pollution, and the main causes and effects of contamination have recently attracted considerable scientific interest [Mazur et al., 2013; Goretti et al., 2016; Parviainen et al., 2016]. The main pollutants in the soil environment are pesticide residues and heavy metal compounds, including copper compounds [Adlassnig et al., 2016]. Water-soluble compounds can penetrate deeper into the soil and contaminate ground water [Fronczyk et al., 2015].

Phytoremediation is a highly promising method of reducing contamination levels in the soil environment [Dhiman et al., 2016]. It relies on the phytostabilization potential of plants which immobilize harmful xenobiotics in soil [Saadani et al., 2016]. One of the greatest advantages of phytoremediation is that it can be applied directly in the polluted site. Heavy metals are easily transferred from contaminated substrates into the food chain, therefore, the chemical composition of crops growing in polluted areas has to be determined to minimize health risks for humans and animals.

Contaminated soil can be treated with amendments which improve the soil structure, increase its sorption capacity, maximize the availability of essential nutrients for plant growth, and immobilize heavy metals. Zeolite and halloysite have unique physicochemical properties, and they can be effectively used to minimize the adverse effects of heavy metal contamination in soils [Radziemska et al., 2013; Radziemska and Mazur, 2016c].

Zeolites are porous aluminosilicates composed of metal oxides and alkaline earth metals with crystalline structure. Their exceptional sorption properties can be attributed to a large specific surface area and high cation exchange capacity [Lee and Valla, 2017]. Halloysite is also characterized by a significantly larger specific surface area and higher cation exchange capacity than other aluminosilicate clay materials. Halloysite occurs naturally in the form of layered cylindrical tubes. It is composed of 
a tetrahedral sheet of silicon oxide and an octahedral sheet of hydrated aluminum oxide [Cravero et al., 2016]. Zeolites and halloysite are widely used in engineering and environmental protection, including in the chemical industry, microelectronics, medicine, construction and agriculture [Bellussi et al., 2015; Li et al., 2016].

The aim of this study was to determine the yield and chemical composition of spring rapeseed (Brassica napus L. var. Napus) plants grown in soil contaminated with copper and amended with halloysite (raw and modified) and zeolite by measuring the content of total $\mathrm{N}, \mathrm{N}-\mathrm{NH}_{4}^{+}, \mathrm{N}^{-\mathrm{NO}_{3}}$, $\mathrm{P}, \mathrm{K}, \mathrm{Na}, \mathrm{Ca}$ and $\mathrm{Mg}$ in the above-ground parts of the tested plants.

\section{MATERIAL AND METHODS}

A greenhouse experiment was performed on samples of topsoil $(0-20 \mathrm{~cm})$ collected in an arable field. The analyzed soil samples had the following granulometric composition: sand $86.6 \%$ (2.0-0.05 mm), silt - $11.2 \%(0.05-0.002$ $\mathrm{mm})$ and clay $-2.2 \%(<0.002 \mathrm{~mm})$. Before the experiment, the $\mathrm{pH}_{\mathrm{KCl}}$ of soil was determined at 6.2 , the content of available nutrients was determined at $58.5 \mathrm{mg} \mathrm{K}, 75.9 \mathrm{mg} \mathrm{Mg}$ and $80.3 \mathrm{mg}$ $\mathrm{P} \cdot \mathrm{kg}^{-1}$ soil, and the content of available organic carbon and total nitrogen was determined at 6.1 $\mathrm{g} \cdot \mathrm{kg}^{-1}$ and $1.02 \mathrm{~g} \cdot \mathrm{kg}^{-1}$ of soil, respectively. The analyzed soil samples had sorption capacity of 87.3 $\mathrm{mmol}(+) \cdot \mathrm{kg}^{-1}$ and base saturation of $71.27 \%$.

The experiment was carried out in three replications, in pots filled with $5 \mathrm{~kg}$ of air-dry soil each. All treatments were supplied with the same macronutrient and micronutrient fertilizer mix $\left(\mathrm{g} \mathrm{kg}^{-1}\right)$ containing $\mathrm{N}-26 \%, \mathrm{~K}_{2} \mathrm{O}-26 \%, \mathrm{~B}-0.013 \%$, $\mathrm{Cu}-0.025 \%, \mathrm{Fe}-0.05 \%, \mathrm{Mn}-0.25 \%$ and $\mathrm{Mo}$ $-0.20 \%$. Experimental treatments were contaminated with copper $\left(\mathrm{CuSO}_{4} \cdot 5 \mathrm{H}_{2} \mathrm{O}\right)$ in three different doses $\left(150,300\right.$ and $\left.450 \mathrm{mg}^{-1} \mathrm{~kg}^{-1}\right)$. The control treatment consisted of soil without the addition of copper or mineral amendments.

The tested plant was spring rapeseed $\mathrm{cv}$. Feliks. The plants were harvested after 65 days in the early flowering stage. The harvested plants were dried, and biomass yield was calculated. The plants were ground in a laboratory mill (Retsch type ZM 300, Hann, Germany) and mineralized. Total nitrogen content was determined by Kjeldahl's method after mineralization in concentrated sulfuric (VI) acid with hydrogen peroxide as a catalyst [Bremner, 1965]. The content of $\mathrm{N}^{-\mathrm{NH}_{4}+}$ was determined with Nessler's reagent [Ostrowska et al., 1991], and the content of $\mathrm{N}^{-\mathrm{NO}_{3}{ }^{-}-\text {with }}$ phenoldisulphonic acid [Ostrowska et al., 1991]. Phosphorus concentration was assessed by colorimetric analysis using the vanadium-molybdenum method [Cavell, 1955]. Sodium, calcium and potassium levels were determined by atomic emission spectrometry (AES) [Szyszko, 1982], and magnesium concentrations - by atomic absorption spectrometry (AAS) [Szyszko, 1982]. Fivepoint calibration was performed with standard solutions. Every sample was analyzed in triplicate. Ultra-pure water with $0.055 \mu \mathrm{Scm}^{-1}$ resistivity was used for preparing the solutions and dilutions.

The results were processed statistically in Statistica 9.1 software (StatSoft, Inc. 2010) by ANOVA and the LSD test at a significance level of $p<0.05$. Boxplots were developed in the XLStat (Addinsoft) application.

\section{RESULTS AND DISCUSSION}

The results of this study and published data suggest that copper's adverse influence on crop yield is determined not only by copper concentration in soil, but also by the applied soil amendments [Yan et al., 2013; Zhang et al., 2014; Radziemska et al., 2016b]. In our study, the above-ground biomass of plants in the control series (without the addition of zeolite or halloysite to copper-contaminated soil) decreased by $9 \%$ in the treatment with the lowest $\mathrm{Cu}$ dose $(150 \mathrm{mg}$ $\mathrm{Cu} \mathrm{kg}{ }^{-1}$ soil) to $62 \%$ in the treatment with the highest $\mathrm{Cu}$ dose (450 $\mathrm{mg} \mathrm{Cu} \mathrm{kg}^{-1}$ soil) (Figure 1). Copper is an essential micronutrient that participates in electron transfer reactions, but it can be toxic for plants and humans at high concentrations [Fernández-Calviño and Bååth, 2016]. The availability of copper is influenced mostly by the organic matter content of soil and soil $\mathrm{pH}$ [Conway and Keller, 2016]. In a study by Kubicka and Jaron [2011], the growth of rye seedlings, in particular the above-ground parts of the analyzed plants, was also stilted under exposure to increasing doses of copper. In our experiment, the addition of mineral adsorbents to soil limited copper's negative influence on plant yield, but the applied minerals differed in their remediation capacity. Both zeolite and halloysite increased the average above-ground biomass of spring rapeseed plants in comparison with control (without the addition 


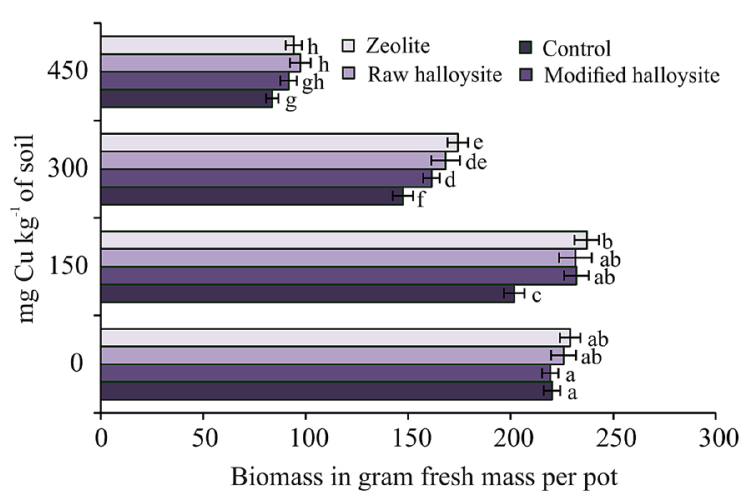

Figure 1. The effect of copper and the tested mineral amendments on the above-ground biomass of spring rapeseed in grams of fresh weight per pot. Error bars represent \pm standard error $(n=3)$. Bars marked with different letters differ significantly $(\mathrm{P}<0.05)$ according to Duncan's test

of mineral adsorbents). Zeolite and raw halloysite contributed to the highest increase in average biomass yield at $13 \%$ and $11 \%$, respectively. In the work of Wyszkowski and Radziemska [2013a, 2013b, 2010], zeolite increased the average yield of aerial parts of oats, spring barley and maize grown in soil polluted with hexavalent chromium. The application of halloysite to nickel-contaminated soil increased the yield of Brassica juncea (L.) [Radziemska et al., 2016d].

The availability of trace elements for plants is determined mainly by the soil environment, mostly soil $\mathrm{pH}$, and the content of humus and mineral colloids [Likar et al., 2015]. Soil contamination with copper has a varied effect on macronutrient and micronutrient concentrations in plants, thus
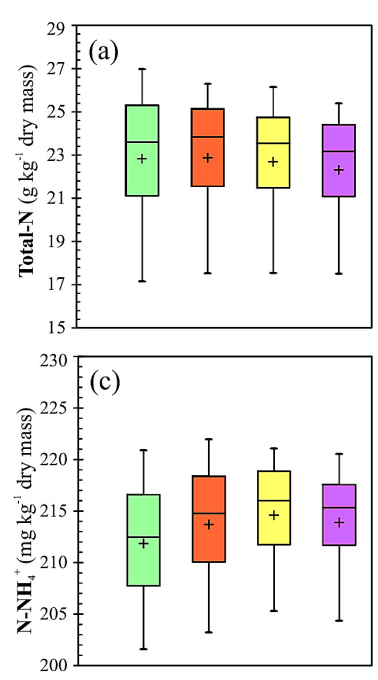

Figure 2. Boxplots showing the median, quartiles, and minimum and maximum values of total $\mathrm{N}$ (a), $\mathrm{N}-\mathrm{NO}_{3}^{-}(\mathrm{b})$ and $\mathrm{N}-\mathrm{NH}_{4}^{+}(\mathrm{c})$ content of spring rapeseed influencing their suitability for processing and consumption [Radziemska et al., 2016b]. In this study, exposure to growing doses of copper led to a $36 \%$ increase in the total nitrogen content of spring rapeseed relative to the control treatment without copper contamination (Figure 2). The tested mineral adsorbents (zeolite, raw and modified halloysite) increased the total nitrogen content of plants, and the highest increase was noted in zeolite treatments. Wyszkowski and Radziemska [2013a] demonstrated that zeolite applied to chromium-contaminated soil had the most profound effect on the nitrogen content of oat grain. In our experiment, both copper and the applied amendments significantly influenced mineral nitrogen levels in spring rapeseed (Figure 2). In treatments without mineral amendments, a negative correlation was observed between increasing copper doses and the content of ammonia nitrogen in the aerial parts of plants. Zeolite as well as raw and modified halloysite increased the concentration of ammonia nitrogen in the above-ground parts of the tested plants, and the greatest increase was noted in treatments supplied with raw and modified halloysite. The accumulation of $\mathrm{N}_{-} \mathrm{NO}_{3}{ }_{3}^{-}$in the aerial parts of spring rapeseed plants grown without the addition of mineral adsorbents was negatively correlated with increasing copper doses. The applied mineral amendments influenced the content of nitrate nitrogen (V) in the aerial parts of the plants (Figure 2). All of the tested mineral adsorbents reduced $\mathrm{N}_{-} \mathrm{NO}_{3}{ }^{-}$concentrations in the above-ground parts of spring rapeseed plants. The application of zeolite to copper-contaminated soil decreased the content of $\mathrm{N}^{-\mathrm{NO}_{3}}{ }_{3}^{-}$in the aerial parts of the tested plants by $11 \%$ relative to control (without soil amendments).

Phosphorus is found in many organic compounds, and it plays a very important role in plants [Arora et al., 2016]. The main source of phosphorus for plants are soluble orthophosphates in the soil solution, including $\mathrm{H}_{2} \mathrm{PO}_{4}$ and, to a lesser degree, $\mathrm{HPO}_{4}$ [Egli et al., 2012]. In plant cells, inorganic phosphorus is accessible from the metabolic pool [Gomes et al., 2014]. In our experiment, the addition of copper and mineral adsorbents to soil significantly influenced the phosphorus content of the aerial parts of spring rapeseed plants (Figure 3). In non-amended treatments, increasing levels of copper contamination increased phosphorus levels in the above-ground parts of the tested plants, and the highest increase of $13 \%$ was observed in the treatment with the highest copper dose (450 mg kg-1 soil). The addi- 
tion of zeolite led to a $9 \%$ increase in the average phosphorus content of plants relative to control. Raw and modified halloysite also increased phosphorus concentrations in plants, but they were less effective than zeolite.

Potassium regulates the water balance in plants, it influences enzyme activity and has a minor influence on biomass yield [Blanch et al., 2014]. The potassium content of the aerial parts of spring rapeseed plants was influenced by the copper dose and the application of mineral adsorbents (Figure 3). In non-amended treatments, potassium concentration in the above-ground parts of the tested plants was positively correlated with increasing copper doses. Mineral amendments increased the average content of potassium in the aerial parts of spring rapeseed plants, and modified halloysite was the most effective adsorbent which led to a $6 \%$ increase in potassium concentrations relative to control.

Plants absorb sodium in the form of $\mathrm{Na}^{+}$ions from the soil solution and the soil sorption complex. Sodium concentrations vary considerably in plants. Sodium and potassium have similar properties, and they exert complementary effects on crop yield [Böhm et al., 2016]. In this experiment,
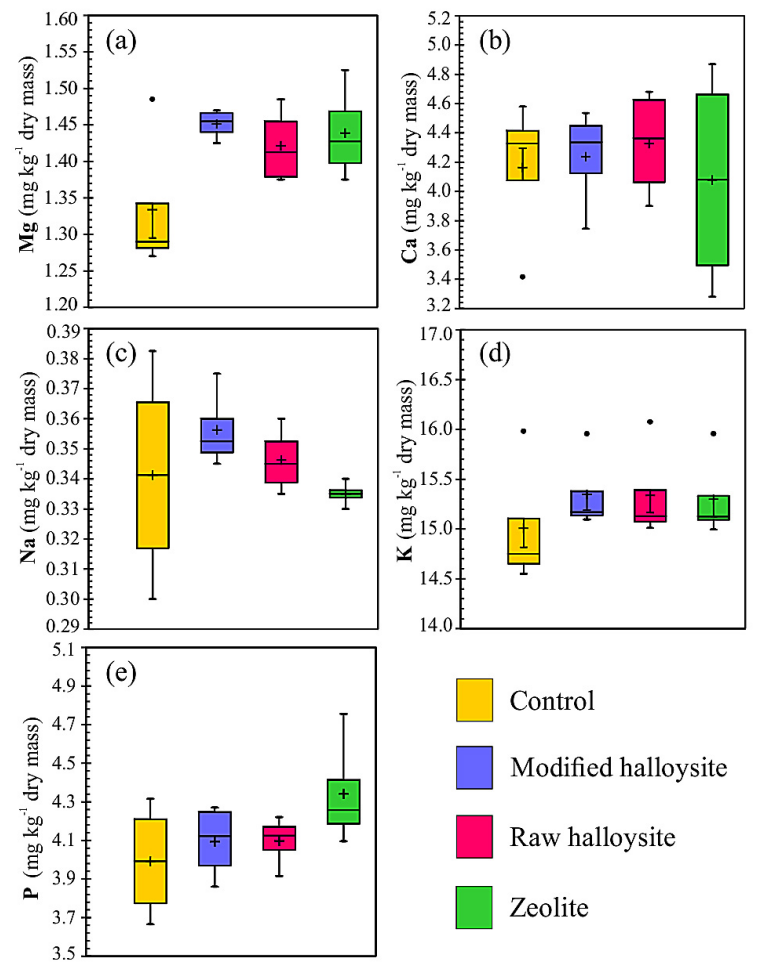

Figure 3. Boxplots showing the median, quartiles, and minimum and maximum values of magnesium (a), calcium (b), sodium (c), potassium (d) and phosphorous (e) concentrations in spring rapeseed the addition of copper and mineral adsorbents had a minor influence on the sodium content of the aerial parts of spring rapeseed plants (Figure 3). In a non-amended treatment exposed to the highest copper dose, sodium concentrations in the aboveground parts of the tested plant increased by $20 \%$. The highest average sodium content was noted in pots treated with raw and modified halloysite. In the studies conducted by of Radziemska et al. [2013], the addition of modified halloysite and zeolite to nickel-contaminated soil also contributed to the accumulation of sodium in the maize.

Calcium ions in the walls of plant cells are balanced with $\mathrm{Ca}^{2+}$ ions in the soil solution [Picard and Chaouki, 2016], whereas roots take up calcium in the form of $\mathrm{Ca}^{2+}$ ions or chelate [Zhang et al., 2016]. The calcium content of the aerial parts of spring rapeseed plants was significantly influenced by the copper dose and the applied mineral adsorbents (Figure 3). In the control series, the exposure to increasing copper doses increased calcium concentrations in the above-ground parts of the tested plants. The application of raw and modified halloysite increased the average calcium content of plants relative to control (without mineral amendments). In a study by Radziemska et al. [2016a, 2016b], sodium concentration in the aerial parts of Indian mustard plants grown in soil with the addition of reactive materials (zerovalent iron, lignite) was generally negatively correlated with increasing levels of chromium (VI) and copper contamination. In the work of Tlustoš et al. [2006], the use of $\mathrm{CaO}$ for soil amendment increased calcium levels in spring wheat plants grown in soil contaminated with heavy metals.

Magnesium is the central element in chlorophyll, which determines the effectiveness of photosynthesis [Zhou et al., 2012]. Magnesium stimulates root growth and nutrient uptake from soil [Jin et al., 2016]. It is a key determinant of root function and cell wall quality, and it directly contributes to plant resistance to adverse environmental conditions [Guo et al., 2016]. In this study, increasing copper doses were positively correlated with the magnesium content of the aerial parts of spring rapeseed plants in non-amended treatments (Figure 3). Magnesium concentration in plants increased by $14 \%$ under exposure to the highest copper dose of $450 \mathrm{mg} \mathrm{Cukg}^{-1}$ soil. The average content of magnesium in plants was also influenced by the applied mineral amendments (zeolite, raw and modified halloysite). Modified halloysite and zeolite induced the greatest increase in magnesium levels in the above-ground 
parts of spring rapeseed plants at $8 \%$ and $9 \%$, respectively. In a study of soil contaminated with zinc, lead and cadmium, the application of dolomite increased the magnesium content of winter wheat grain and straw [Leszczyńska and Kwiatkowska-Malina, 2012]. In the work of Radziemska et al. [2013], the addition of zeolite and modified halloysite to nickel-contaminated soil also contributed to the accumulation of magnesium in the tested plants.

\section{CONCLUSIONS}

The amendments applied in the experiment (zeolite, raw and modified halloysite) significantly influenced the total nitrogen content, concentrations of ammonia nitrogen, nitrate nitrogen, phosphorus, potassium, sodium, calcium and magnesium, and the above-ground biomass of spring rapeseed plants. The addition of zeolite, raw and modified halloysite to soil minimized copper's adverse effects on the yield of spring rapeseed, but the tested mineral amendments differed in their effectiveness. In comparison with control, zeolite and halloysite had the most beneficial effect on the average biomass yield of spring rapeseed. Modified halloysite contributed to an increase in the average concentrations of ammonia nitrogen, potassium, sodium, calcium and magnesium in spring rapeseed. Raw halloysite increased the content of sodium and calcium in the tested plants. The greatest increase in the phosphorus content of spring rapeseed was observed in treatments amended with zeolite. Zeolite also exerted a beneficial effect on the content of total nitrogen and ammonia nitrogen in the above-ground parts of spring rapeseed plants.

\section{REFERENCES}

1. Adlassnig W., Weiss Y.S., Sassmann S., Steinhauser G., Hofhansl F., Baumann N., Lichtscheidl I.K. Lang I. 2016. The copper spoil heap Knappenberg, Austria, as a model for metal habitats - Vegetation, substrate and contamination. Science of the Total Environment, 563-564, 1037-1049.

2. Arora N., Patel A., Pruthi P.A., Pruthi V. 2016. Synergistic dynamics of nitrogen and phosphorous influences lipid productivity in Chlorella minutissima for biodiesel production. Bioresource Technology, 213, 79-87.

3. Bellussi G., Millini R., Pollese P. 2015. An industrial perspective on the impact of Haldor Topsøe on research and development in catalysis by zeolites. Journal of Catalysis, 328, 11-18.

4. Blanch M., Fernandez-Caballero C., Sanchez-Ballesta M.T., Escribano M.I., Merodio C. 2014. Accumulation and distribution of potassium and its association with water balance in the skin of Cardinal table grapes during storage. Scientia Horticulturae, $175,223-228$.

5. Bremner J.M. 1965. Total nitrogen. In: Methods of soil analysis, part 2. Chemical and microbiological properties. Black CA et al. (eds). American Society of Agronomy, Madison, WI. Agronomy, 9, 1149-1178.

6. Böhm J., Scherzer S., Shabala S., Krol E., Neher E., Mueller T.D., Hedrich R. 2016. Venus flytrap HKT1type channel provides for prey sodium uptake into carnivorous plant without conflicting with electrical excitability. Molecular Plant, 9, 3, 428-436.

7. Cavell A.J. 1955. The colorimetric determination of phosphorous in plant materials. Journal of the Science of Food and Agriculture, 6, 479-481.

8. Conway J.R., Keller A.A. 2016. Gravity-driven transport of three engineered nanomaterials in unsaturated soils and their effects on soil $\mathrm{pH}$ and nutrient release. Water Research, 98, 250-260.

9. Cravero F., Fernández L., Marfil S., Sánchez M., Maiza P., Martínez A. 2016. Spheroidal halloysites from Patagonia, Argentina: Some aspects of their formation and applications. Applied Clay Science, 131, 48-58.

10. Dhiman S.S., Selvaraj C., Li J., Singh R., Zhao X., Kim D., Kim J.Y., Kang Y.C., Lee J.K. 2016. Phytoremediation of metal-contaminated soils by the hyperaccumulator canola (Brassica napus L.) and the use of its biomass for ethanol production. Fuel, $183,107-114$.

11. Egli M., Filip D., Mavris C., Fischer B., Götze J., Raimondi S., Seibert J. 2012. Rapid transformation of inorganic to organic and plant-available phosphorous in soils of a glacier fore field. Geoderma, 189-190, 215-226.

12. Fernández-Calviño D., Bååth E. 2016. Interaction between $\mathrm{pH}$ and $\mathrm{Cu}$ toxicity on fungal and bacterial performance in soil. Soil Biology and Biochemistry, 96, 20-29.

13. Fronczyk J. Radziemska M., Mazur Z. 2015. Copper removal from contaminated groundwater using natural and engineered limestone sand in permeable reactive barriers. Fresenius Environmental Bulletin, 24, 1a, 228-234.

14. Gomes M.P., Soares A.M., Garcia Q.S. 2014. Phosphorous and sulfur nutrition modulate antioxidant defenses in Myracrodruom urundeuva plants exposed to arsenic. Journal of Hazardous Materials, 276, 97-104.

15. Goretti E., Pallottini M., Ricciarini M.I., Selvaggi R., Cappelletti D. 2016. Heavy metals bioaccumulation in selected tissues of red swamp cray fish: An easy tool for monitoring environmental contamination levels. Science of the Total Environment, 559, 339-346. 
16. Guo W., Nazim H., Liang Z., Yang D. 2016. Magnesium deficiency in plants: An urgent problem. The Crop Journal, 4, 2, 83-91.

17. Jin X.L, Ma C.L, Yang L.T., Chen L.S. 2016. Alterations of physiology and gene expression due to long-term magnesium-deficiency differ between leaves and roots of Citrus reticulata. Journal of Plant Physiology, 198, 103-115.

18. Kubicka H., Jaroń N. 2016. The action of copper ions on the growth of inbred lines of rye seedlings (Secale cereale L.). Environmental Protection and Natural Resources, 48, 96-103 [in Polish].

19. Leszczyńska D., Kwiatkowska-Malina J. 2012. Effect of soil contamination on yield and content of main macroelements in winter wheat. Proceedings of ECOpole, 6, 2, 743-748.

20. Lee K.X., Valla J.A. 2017. Investigation of metalexchanged mesoporous Y zeolites for the adsorptive desulfurization of liquid fuels. Applied Catalysis B: Environmental, 201, 359-369

21. Li X., Yang Q., Ouyang J., Yang H., Chang S. 2016. Chitosan modified halloysite nanotubes as emerging porous microspheres for drug carrier. Applied Clay Science, 126, 306-312.

22. Likar M., Vogel-Mikus K., Potisek M., Hancevic K., Radic T., Necemer M., Regvar M. 2015. Importance of soil and vineyard management in the determination of grapevine mineral composition. Science of the Total Environment, 505, 724-731.

23. Mazur Z., Radziemska M., Maczuga O., Makuch A. 2013. Heavy metal concentrations in soil and moss surroundings railroad. Fresenius Environmental Bulletin, 22, 4, 955-961.

24. Ostrowska A., Gawliński S., Szczubiałka Z. 1991. Methods for analysis and evaluation of soil and plant properties. IOŚ Warsaw, 334 pp.

25. Parviainen A., Suárez-Grau J.M., Pérez-López R., Nieto J.M., Garrido C.J., Cobo-Cárdenas G. 2016. Combined microstructural and mineralogical phase characterization of gallstones in a patient-based study in SW Spain - Implications for environmental contamination in their formation. Science of the Total Environment, 573, 433-443.

26. Picard F., Chaouki J. 2016. Selective extraction of heavy metals from two real calcium-rich contaminated soils by a modified NTA. Journal of Hazardous Materials, 318, 48-53.

27. Radziemska M., Mazur Z., Jeznach J. 2013. Influence of applying halloysite and zeolite to soil contaminated with nickel on the content of selected elements in Maize (Zea mays L.). Chemical Engineering Transactions, 32, 301-306.

28. Radziemska M., Jeznach J., Mazur Z., Fronczyk J., Bilgin A. 2016a. Assessment of the effect of reactive materials on the content of selected elements in Indian mustard grown in $\mathrm{Cu}$-contaminated soils. Journal of Water and Land Development, 28, 53-60.

29. Radziemska M., Mazur Z., Fronczyk J., Jeznach J. 2016b. Effect of reactive materials on the content of selected elements in Indian mustard grown in $\mathrm{Cr}(\mathrm{VI})$-contaminated soils. Journal of Ecological Engineering, 17, 2, 141-147.

30. Radziemska M., Mazur Z. 2016c. Content of selected heavy metals in Ni-contaminated soil following the application of halloysite and zeolite. Journal of Ecological Engineering, 17, 3, 125-133.

31. Radziemska M., Mazur Z., Fronczyk J., Matusik J. 2016d. Co-remediation of Ni-contaminated soil by halloysite and Indian mustard (Brassica juncea L.). Clay Minerals, 51, 489-497.

32. Saadani O., Fatnassi I.C., Chibou M., Abdelkrim S., Barhoumi F., Jebara M., Jebara S.H. 2016. In situ phytostabilisation capacity of three legumes and their associated Plant Growth Promoting Bacteria (PG$\mathrm{PBs}$ ) in mine tailings of northern Tunisia. Ecotoxicology and Environmental Safety, 130, 263-269.

33. Szyszko E. 1982. Instrumental analytical method. PZWL Warsaw, pp. 623

34. Tlustoš P., Száková J., Korínek K., Pavlíková D., Hanč A.; Balík J. 2006. The effect of liming on cadmium, lead, and zinc uptake reduction by spring wheat grown in contaminated soil. Plant, Soil and Environment, 52, 1, 16-24.

35. Wyszkowski M., Radziemska M. 2010. Effects of chromium (III and VI) on spring barley and maize biomass yield and content of nitrogenous compounds. Journal of Toxicology and Environmental Health, Part A, 73, 17-18, 1274-1282.

36. Wyszkowski M., Radziemska M. 2013a. Assessment of tri- and hexavalent chromium phytotoxicity on Oats (Avena sativa L.) biomass and content of nitrogen compounds. Water Air and Soil Pollution, 244, 1619-1632.

37. Wyszkowski M., Radziemska M. 2013b. Influence of chromium (III) and (VI) on the concentration of mineral elements in oat (Avena sativa L.). Fresenius Environmental Bulletin, 22, 4, 979-986.

38. Yan X., Wang H., Wang Q., Rudstam L.G. 2013. Risk spreading, habitat selection and division of biomass in a submerged clonal plant: Responses to heterogeneous copper pollution. Environmental Pollution, 174, 114-120.

39. Zhang L., Pan Y., Lv W., Xiong Z.T. 2014. Physiological responses of biomass allocation, root architecture, and invertase activity to copper stress in young seedlings from two populations of Kummerowia stipulacea (maxim.) Makino. Ecotoxicology and Environmental Safety, 104, 278-284.

40. Zhang X., Wang L., Zhou A., Zhou Q., Huang X. 2016. Alterations in cytosol free calcium in horseradish roots simultaneously exposed to lanthanum(III) and acid rain. Ecotoxicology and Environmental Safety, 126, 62-70.

41. Zhou S., Sawicki A., Willows R.D., Luo M. 2012. C-terminal residues of Oryza sativa GUN4 are required for the activation of the $\mathrm{ChlH}$ subunit of magnesium chelatase in chlorophyll synthesis. FEBS Letters, 586, 3, 205-210. 